\title{
Optimization, Equilibrium and Kinetic Modeling of Methylene Blue Removal from Aqueous Solutions Using Dry Bean Pods Husks Powder
}

\author{
Giannin Mosoarca (D), Simona Popa *, Cosmin Vancea * and Sorina Boran
}

check for

updates

Citation: Mosoarca, G.; Popa, S.; Vancea, C.; Boran, S. Optimization, Equilibrium and Kinetic Modeling of Methylene Blue Removal from Aqueous Solutions Using Dry Bean Pods Husks Powder. Materials 2021, 14, 5673. https://doi.org/10.3390/ ma14195673

Academic Editor: Elena

Niculina Dragoi

Received: 6 September 2021

Accepted: 25 September 2021

Published: 29 September 2021

Publisher's Note: MDPI stays neutral with regard to jurisdictional claims in published maps and institutional affiliations.

Copyright: (c) 2021 by the authors. Licensee MDPI, Basel, Switzerland. This article is an open access article distributed under the terms and conditions of the Creative Commons Attribution (CC BY) license (https:/ / creativecommons.org/licenses/by/ $4.0 /)$.
Faculty of Industrial Chemistry and Environmental Engineering, Politehnica University Timisoara, Bd. V. Parvan No. 6, 300223 Timisoara, Romania; giannin.mosoarca@upt.ro (G.M.); sorina.boran@upt.ro (S.B.)

* Correspondence: simona.popa@upt.ro (S.P.); cosmin.vancea@upt.ro (C.V.); Tel.: +40-256404212 (S.P.); +40-256404194 (C.V.)

\begin{abstract}
In this research, dry bean pods husks (DBPH) were used as an adsorbent material after minimum processing (without chemical substances consumption and without thermal treatment) to remove methylene blue from aqueous solutions. The adsorbent surface characteristics were investigated using SEM and FTIR analysis. For maximum removal efficiency, several parameters that influence the dye adsorption were optimized using the Taguchi method. Equilibrium and kinetic modeling, along with thermodynamic studies, were conducted to elucidate the adsorption mechanism. Taguchi experimental design showed that the factor with the highest influence was the adsorbent dose, with a percent contribution established by the ANOVA analysis of $40.89 \%$. Langmuir isotherm and pseudo-second order kinetic model characterizes the adsorption process. The maximum adsorption capacity, $121.16\left(\mathrm{mg} \mathrm{g}^{-1}\right)$, is higher than other similar adsorbents presented in scientific literature. Thermodynamic parameters indicate a spontaneous, favorable and endothermic adsorption process, and their values show that physical adsorption is involved in the process. The obtained results, and the fact that adsorbent material is inexpensive and easily available, indicate that DBPH powder represents an effective absorbent for treating waters containing methylene blue. Additionally, the Taguchi method is very suitable to optimize the process.
\end{abstract}

Keywords: optimization; Taguchi method; methylene blue; adsorption; equilibrium modeling; kinetics; thermodynamics

\section{Introduction}

Dyes are an important category of compounds widely used in many industries: textile, dye, plastic, paper, leather, rubber and cosmetics [1-9]. The residual effluents can contain variable amounts of dyes and without prior treatment, before discharge, they can cause serious problems both to the environment and human health [2,3,6,7,9-11].

Methylene blue (MB) dye is used in many industrial fields as well as in medicine. Even if it is not very toxic and dangerous, this compound can cause negative effects on human health: respiratory problems, vomiting, increased heart rate, cyanosis, eye irritation, nausea, methemoglobinemia, diarrhea and jaundice $[2,9,11-17]$. Therefore, its removal from process effluents is absolutely required.

Unlike other methods used to remove dyes from wastewater (coagulation, precipitation, ion exchange, membrane processes, chemical oxidation, electrochemical processes, biodegradation), adsorption has several essential advantages such as high efficiency, ease of operation, flexibility and low costs $[1,3,4,6-10,12-18]$.

The actual trend is to identify various new low-cost adsorbents such as natural materials, industrial wastes, agricultural wastes and bioadsorbents [1,3,8,12-14].

Another major advantage is the fact that the adsorption process can be easily optimized and modeled [19-24]. 
The Taguchi method is used to optimize various processes without increasing costs. It allows understanding the effect of variable process parameters in a small number of experimental tests, and the results obtained lead to improved process performance [19,21-26]. The Taguchi method uses an orthogonal array that distributes the variables in a balanced way, and the experimental results are converted into a signal-to-noise ratio (S/N). The optimal value of the process parameters is given by the highest $\mathrm{S} / \mathrm{N}$ ratio $[19,21,22]$.

Common bean (Phaseolus vulgaris L.) is an important legume that grows in subtropical and temperate regions. Its seeds are a very important source of food for large parts of the population due to its nutritional properties (high source of dietary fiber and proteins, low level of lipids), low cost and long-term storage possibility. Almost 27 million tones of beans are produced annually in the world [27-29]. If common bean is grown for dry beans, a significant amount of dry pod husks results after harvesting and separation of the grains.

The aim of the present paper was to use this product, after minimum processing (without chemical substances consumption and without thermal treatment), to remove methylene blue dye from aqueous solutions by adsorption. Scanning electron microscopy (SEM) and Fourier transform infrared spectroscopy (FTIR) were carried out to study the adsorbent surface characteristics. For maximum removal efficiency the parameters that influenced the adsorption process were optimized by using the Taguchi method. For a description of the adsorption process, equilibrium, kinetics and thermodynamic parameters were calculated and discussed.

\section{Materials and Methods}

\subsection{Adsorbent Preparation and Characterization}

Dry bean pods husks (DBPH) were provided by a local agricultural producer from Cerneteaz village, Romania. The husks were first washed using distilled water, then dried at room temperature for three days and then at $90{ }^{\circ} \mathrm{C}$ for $24 \mathrm{~h}$. The next operations to which the material was subjected were grinding (with an electric mill), passing over a sieve (with a mesh diameter of $2 \mathrm{~mm}$ ), washing with distilled water (for turbidity and color removal) and drying at $105^{\circ} \mathrm{C}$ for $5 \mathrm{~h}$.

SEM analysis (Quanta FEG 250 microscope, at 1600× magnitude) was used to study the surface morphology of the adsorbent material. Identification of functional groups of the adsorbent was performed by FTIR spectroscopy (Shimadzu Prestige-21 FTIR spectrophotometer). The FTIR spectrum was recorded after the solid adsorbent sample was ground with IR transparent potassium bromide $(\mathrm{KBr})$ and then pressed into a pellet.

\subsection{Taguchi Experimental Design}

The Taguchi (L27) orthogonal array was used to establish the optimum conditions for the dye removal by adsorption. The effect of five factors, at three levels, on the removal efficiency of dye was studied. Table 1 presents the controllable factors and their levels, which were used in the Taguchi design.

Table 1. The controllable parameters and their levels.

\begin{tabular}{cccc}
\hline Parameter & Level 1 & Level 2 & Level 3 \\
\hline $\mathrm{pH}$ & 2 & 6 & 10 \\
Time $(\mathrm{min})$ & 5 & 30 & 50 \\
Adsorbent dose $\left(\mathrm{mg} \mathrm{L}^{-1}\right)$ & 0.5 & 1.5 & 2.5 \\
Initial dye concentration $\left(\mathrm{mg} \mathrm{L}^{-1}\right)$ & 50 & 150 & 250 \\
Temperature $(\mathrm{K})$ & 285 & 296 & 306 \\
\hline
\end{tabular}

The Taguchi approach converted the obtained experimental results into a signal-tonoise $(\mathrm{S} / \mathrm{N})$ ratio, which was used to analyze the experiment quality and the validity of the result. The terms "signal" and "noise" represent the desirable value (mean) and the undesirable value (standard deviation) for the output characteristic, respectively. To evaluate the experimental results, the highest adsorption efficiency was considered. In 
analyzing the signal-to-noise ratio of the Taguchi method, the "larger-the-better" option (Equation (1)) was chosen [19,30-32]:

$$
\frac{S}{N}=-\log _{10}\left[\frac{1}{n} \sum_{i=1}^{n}\left(\frac{1}{y_{i}}\right)^{2}\right]
$$

where: $n$ represents the repetitions number under similar experimental conditions, and $y_{i}$ represents the experimental response.

The $\mathrm{S} / \mathrm{N}$ ratio was calculated and analyzed using the Minitab19 software.

To establish the percentage contribution of each factor to the efficiency of MB removal and to evaluate the results of the Taguchi model, an analysis of variance (ANOVA-General Linear Model) was used [19,30-33]. The necessary calculations were performed with the Minitab 19 software.

\subsection{Adsorption Experimental Studies}

The adsorption studies were performed at constant mixing intensity, in Erlenmeyer flasks, using $50 \mathrm{~mL}$ of $\mathrm{MB}$ solution together with the adsorbent material. The $\mathrm{pH}$ adjustment was realized with dilute solutions of $\mathrm{NaOH}$ and $\mathrm{HCl}(0.1 \mathrm{~N})$. The dye concentration was determined by a UV-VIS spectrophotometer at $664 \mathrm{~nm}$ wavelength.

The adsorption capacity at equilibrium, $\left(q_{e}\right)$, and at time $t,\left(q_{t}\right)$, were calculated with Equations (2) and (3), while the dye removal percentage $R(\%)$ was calculated with Equation (4) $[4,9,10,12,14]$ :

$$
\begin{aligned}
q_{e} & =\frac{\left(C_{0}-C_{e}\right) \cdot V}{m} \\
q_{t} & =\frac{\left(C_{0}-C_{t}\right) \cdot V}{m} \\
R(\%) & =\frac{\left(C_{0}-C_{e}\right)}{C_{0}} \times 100
\end{aligned}
$$

where: $C_{0}$ represents the initial $\mathrm{MB}$ concentration $\left(\mathrm{mg} \mathrm{L}^{-1}\right), C_{e}$ represents the MB equilibrium concentration $\left(\mathrm{mg} \mathrm{L}^{-1}\right), C_{t}$ represents the $\mathrm{MB}$ concentration at time $t\left(\mathrm{mg} \mathrm{L}^{-1}\right), V$ represents the solution volume $(\mathrm{L})$ and $m$ represents the mass of adsorbent $(\mathrm{g})$.

\subsection{Equilibrium and Kinetic Modeling}

Adsorption isotherms are very important for describing the solid-liquid adsorption process. The Langmuir and Freundlich isotherms were used to investigate the adsorption behavior. Their equations are presented below:

$$
\begin{array}{ll}
\text { Langmuir isotherm : } & q_{e}=\frac{q_{m} \cdot K_{L} \cdot C_{e}}{1+K_{L} \cdot C_{e}}, \\
\text { Freundlich isotherm : } & q_{e}=K_{F} \cdot C_{e}^{1 / n_{F}},
\end{array}
$$

where: $q_{m}$ represents the maximum absorption capacity $\left(\mathrm{mg} \mathrm{g}^{-1}\right), K_{L}$ represents the Langmuir constant, $K_{F}$ represents the Freundlich constant and $1 / n_{F}$ represents an empirical constant indicating the adsorption intensity [34-38].

A lot of useful information on the mechanism and efficiency of adsorption used to design an industrial treatment plant is provided by kinetics studies. The pseudo-first-order and pseudo-second-order models were used to model the experimental data.

$$
\begin{gathered}
\text { Pseudo-first-order model equation : } \quad q_{t}=q_{e}\left(1-\exp ^{-k_{1} \cdot t}\right), \\
\text { Pseudo-second-order model equation : } \quad q_{t}=\frac{k_{2} \cdot t \cdot q_{e}^{2}}{1+k_{2} \cdot t \cdot q_{e}},
\end{gathered}
$$


where: $k_{1}$ represents the pseudo-first-order model rate constant, and $k_{2}$ represents the pseudo-second-order model rate constant [34-38].

To establish the best-fitting kinetic and equilibrium models, the values of determination coefficient $\left(R^{2}\right)$, sum of square error (SSE), chi-square $\left(\chi^{2}\right)$ and average relative error $(A R E)$ were determined with the equations described below [37]. The higher value for $R^{2}$ and the smaller values for $S S E, \chi^{2}$ and $A R E$ were taken into account when choosing the most suitable models.

$$
\begin{gathered}
R^{2}=1-\frac{\sum_{i=1}^{n}\left(y_{i, \exp }-y_{i, \text { mod }}\right)^{2}}{\sum_{i=1}^{n}\left(y_{i, \text { exp }}-\overline{y_{i, \text { exp }}}\right)^{2}} \\
S S E=\sum_{i=1}^{n}\left(y_{i, \text { exp }}-y_{i, \text { mod }}\right)^{2} \\
\chi^{2}=\sum_{i=1}^{n} \frac{\left(y_{i, \text { exp }}-y_{i, \text { mod }}\right)^{2}}{y_{i, \text { mod }}} \\
A R E=\frac{100}{n} \sum_{i=1}^{n}\left|\frac{y_{i, \text { exp }}-y_{i, \text { mod }}}{y_{i, \text { mod }}}\right|
\end{gathered}
$$

where: $y_{i, \exp }$ represents the independent variable experimental value, $y_{i, m o d}$ represents the modeled value, $\overline{y_{i, \exp }}$ represents the observed values mean o and $n$ is the information total number.

\subsection{Thermodynamic Parameter Determination}

The data of methylene blue adsorption, at different temperatures (285, 296 and $306 \mathrm{~K})$, were used to determine Gibbs free energy change, enthalpy change and entropy change, according to the following equations $[37,39,40]$ :

$$
\begin{gathered}
\Delta G^{0}=-R T \ln K_{L} \\
\ln K_{L}=\frac{\Delta S^{0}}{R}-\frac{\Delta H^{0}}{R T}
\end{gathered}
$$

where: $R$ represents the universal gas constant, $K_{L}$ represents the Langmuir constant and $T$ represents the absolute temperature.

\subsection{Desorption Experimental Studies}

In the desorption studies, the MB-loaded adsorbent was mixed with various desorption agents: $0.1 \mathrm{~N} \mathrm{HCl}, 0.1 \mathrm{~N} \mathrm{NaOH}$ and distilled water.

The desorption percent $D(\%)$ of dye was calculated with Equation (15):

$$
D(\%)=\frac{m_{d}}{m_{a}} \times 100
$$

where: $m_{d}$ represents amount of dye liberated by desorbing agent, and $m_{a}$ represents amount of dye adsorbed on adsorbent.

\section{Results and Discussion}

\subsection{Adsorbent Material Characterization}

SEM analysis of the adsorbent material showed the presence of irregular pores with different shapes and sizes on its surface (Figure 1a). After adsorption, the surface was modified, and the pores were covered by dye molecules (Figure 1b). 

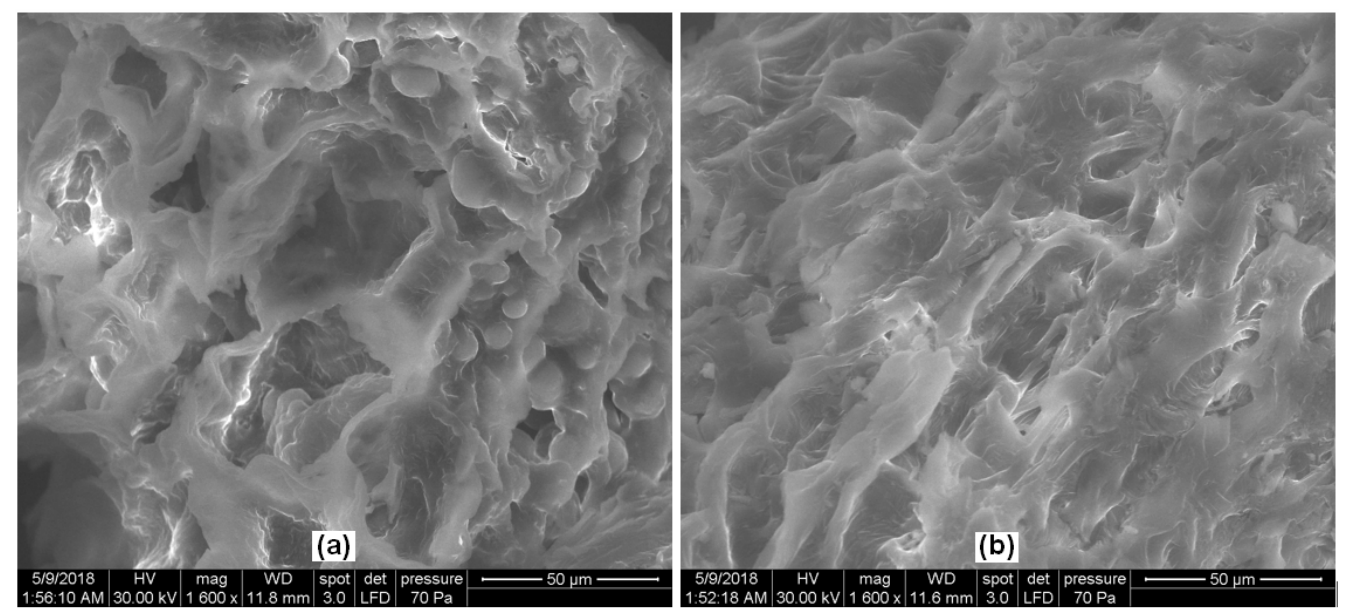

Figure 1. Scanning electron microscopy images of DBPH powder: (a) before and (b) after MB adsorption.

FTIR spectroscopy was used to identify the presence of different functional groups on the surface of adsorbent. The FTIR spectra illustrated in Figure 2 suggest cellulose and hemicellulose as main components. The differences between the peak's wavenumber before and after adsorption are less than $10 \mathrm{~cm}^{-1}$, indicating an adsorption mechanism that could include physical interaction or ion-exchange mechanism [41].

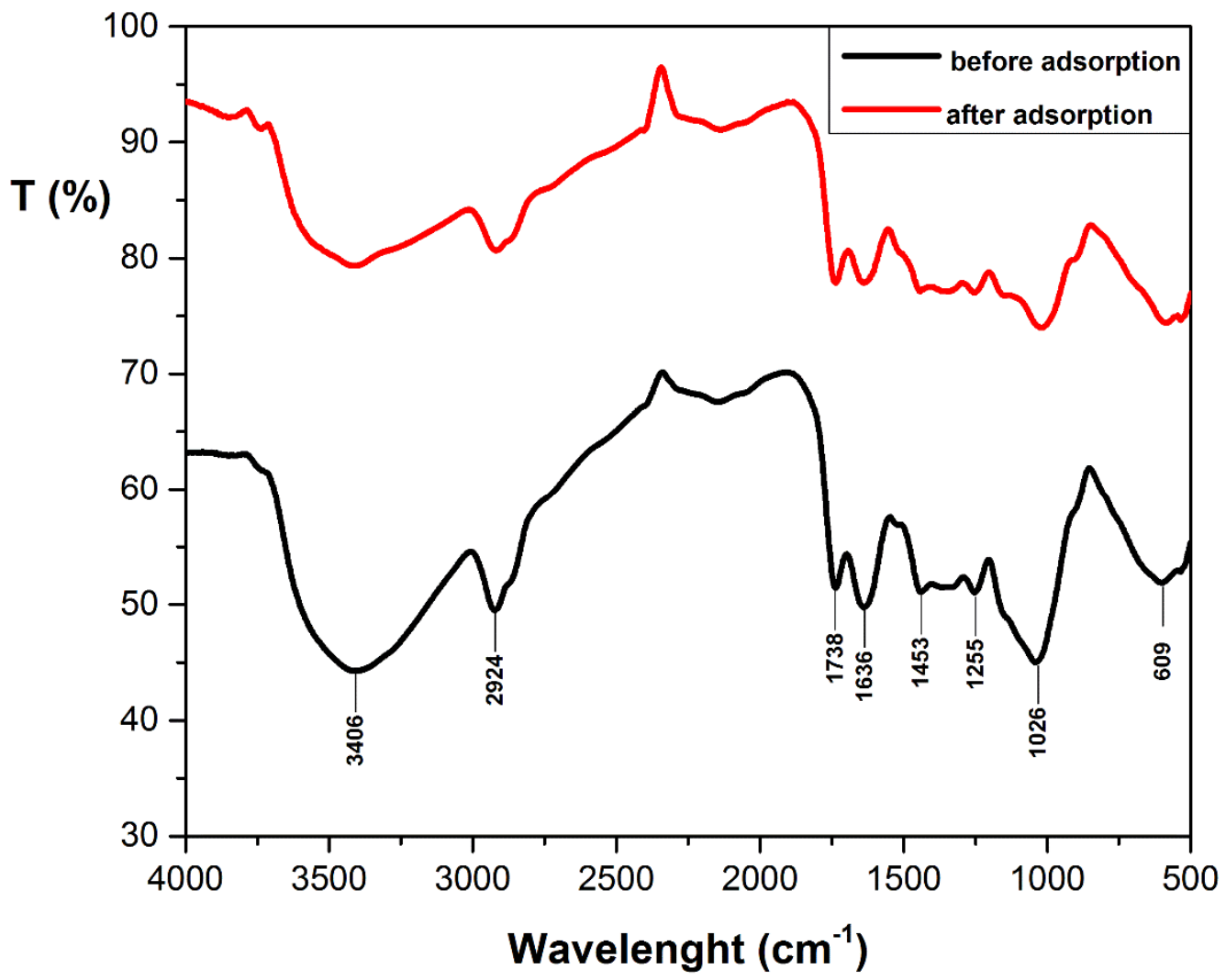

Figure 2. FT-IR spectrum of DBPH powder.

The specific peaks of the main functional group are: $3406 \mathrm{~cm}^{-1}$-strong absorption peaks of O-H stretching vibration [42]; $2924 \mathrm{~cm}^{-1}$ - the peak belongs to $-\mathrm{CH}_{2}$ groups of cellulose [43]; $1738 \mathrm{~cm}^{-1}-\mathrm{C}=\mathrm{O}$ stretching vibration of carboxylic groups of hemicellulose [44]; $1636 \mathrm{~cm}^{-1}-\mathrm{O}-\mathrm{H}$ bending vibration of water sorption characteristics of cellulose [45]; $1453 \mathrm{~cm}^{-1}$ — the peak belongs to the bending of - $\mathrm{CH}$ groups of cellulose [43]; 
$1255 \mathrm{~cm}^{-1}-\mathrm{C}-\mathrm{O}$ stretching and $\mathrm{CH}$ or $\mathrm{OH}$ bending of hemicellulose structures [40,46]; $1026 \mathrm{~cm}^{-1}-\mathrm{C}-\mathrm{O}, \mathrm{C}-\mathrm{O}-\mathrm{H}, \mathrm{C}-\mathrm{O}-\mathrm{C}, \mathrm{C}-\mathrm{C}$, ring stretching vibration in cellulose and hemicellulose [47]; $609 \mathrm{~cm}^{-1}$ - the bending modes of aromatic compounds of cellulose [48].

\subsection{Optimization of Adsorption Parameters}

Five controllable factors at three levels were used in the Taguchi design to estimate the optimum conditions for MB adsorption. Table 2 shows the L27 orthogonal array and results obtained after each run. Using the rank of $\mathrm{S} / \mathrm{N}$ ratio, along with total increments (delta values), the order of the controllable factors' significance was determined (Table 3). The delta value measures the magnitude of the effect considering the difference between the highest and lowest characteristic average for a controllable factor [19]. The factor that had the greatest influence on the process was the adsorbent dose, while the factor with the least influence was temperature. The optimum conditions of adsorption are also marked in Table 3.

Table 2. Experimental layout of L27 orthogonal array and results obtained for removal efficiency and S/N ratios.

\begin{tabular}{|c|c|c|c|c|c|c|}
\hline $\mathrm{pH}$ & Time & Adsorbent Dose & Initial Dye Concentration & Temperature & Dye Removal Efficiency & S/N Ratio \\
\hline 2 & 5 & 0.5 & 50 & 285 & 38.81 & 31.77 \\
\hline 2 & 5 & 0.5 & 50 & 296 & 42.22 & 32.51 \\
\hline 2 & 5 & 0.5 & 50 & 306 & 42.62 & 32.59 \\
\hline 2 & 30 & 1.5 & 150 & 285 & 53.95 & 34.63 \\
\hline 2 & 30 & 1.5 & 150 & 296 & 58.69 & 35.37 \\
\hline 2 & 30 & 1.5 & 150 & 306 & 59.24 & 35.45 \\
\hline 2 & 50 & 2.5 & 250 & 285 & 53.35 & 34.54 \\
\hline 2 & 50 & 2.5 & 250 & 296 & 58.04 & 35.27 \\
\hline 2 & 50 & 2.5 & 250 & 306 & 58.58 & 35.35 \\
\hline 6 & 5 & 1.5 & 250 & 285 & 48.67 & 33.74 \\
\hline 6 & 5 & 1.5 & 250 & 296 & 52.97 & 34.48 \\
\hline 6 & 5 & 1.5 & 250 & 306 & 53.44 & 34.55 \\
\hline 6 & 30 & 2.5 & 50 & 285 & 80.12 & 38.07 \\
\hline 6 & 30 & 2.5 & 50 & 296 & 87.16 & 38.80 \\
\hline 6 & 30 & 2.5 & 50 & 306 & 87.98 & 38.88 \\
\hline 6 & 50 & 0.5 & 150 & 285 & 52.94 & 34.47 \\
\hline 6 & 50 & 0.5 & 150 & 296 & 57.59 & 35.20 \\
\hline 6 & 50 & 0.5 & 150 & 306 & 58.13 & 35.28 \\
\hline 10 & 5 & 2.5 & 150 & 285 & 63.67 & 36.07 \\
\hline 10 & 5 & 2.5 & 150 & 296 & 69.26 & 36.80 \\
\hline 10 & 5 & 2.5 & 150 & 306 & 69.91 & 36.89 \\
\hline 10 & 30 & 0.5 & 250 & 285 & 48.73 & 33.75 \\
\hline 10 & 30 & 0.5 & 250 & 296 & 53.01 & 34.48 \\
\hline 10 & 30 & 0.5 & 250 & 306 & 53.51 & 34.56 \\
\hline 10 & 50 & 1.5 & 50 & 285 & 74.66 & 37.46 \\
\hline 10 & 50 & 1.5 & 50 & 296 & 81.21 & 38.19 \\
\hline 10 & 50 & 1.5 & 50 & 306 & 81.98 & 38.27 \\
\hline
\end{tabular}

Table 3. Signal-to-noise S/N ratios response.

\begin{tabular}{cccccc}
\hline Level & $\mathbf{p H}$ & Time & Adsorbent Dose & Initial Dye Concentration & Temperature \\
\hline 1 & 34.17 & 34.38 & 33.85 & $36.29 *$ & 34.95 \\
2 & 35.95 & 36.00 & 35.80 & 35.58 & 35.68 \\
3 & $36.28^{*}$ & $36.01^{*}$ & $36.75 *$ & 1.76 & $35.76^{*}$ \\
Delta & 2.11 & 1.63 & 2.90 & 3 & 51 \\
Rank & 2 & 4 & 1 & 5 & 5 \\
\hline
\end{tabular}

* The maximum $\mathrm{S} / \mathrm{N}$ ratio indicates the optimum condition. 
Figure 3 shows comparatively the response curves for the individual effects of dye adsorption parameters on the $\mathrm{S} / \mathrm{N}$ ratio and dye removal efficiency.

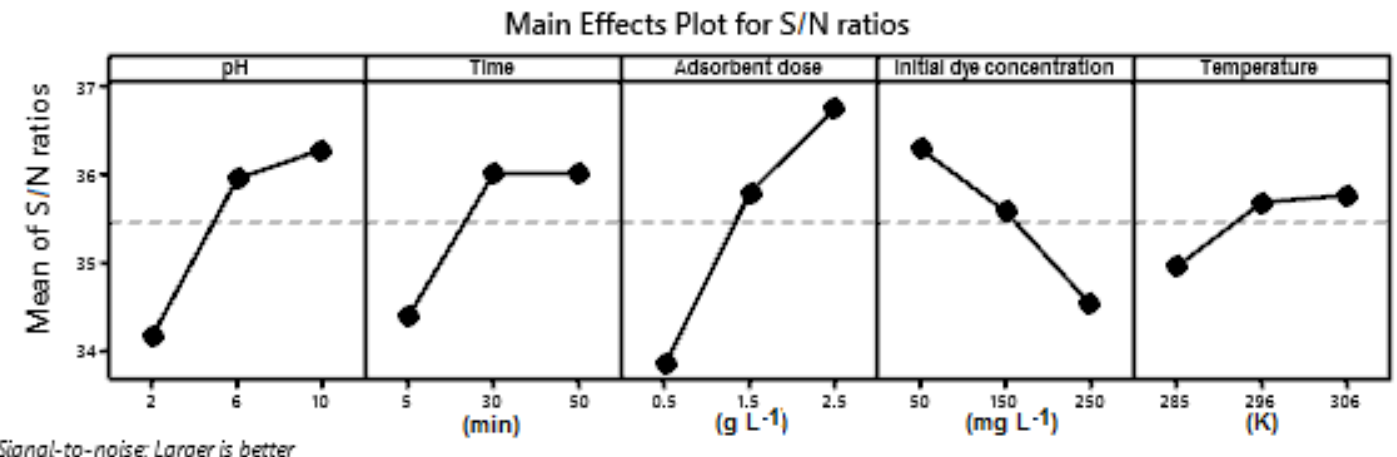

Signal-to-noise: Lorger is better

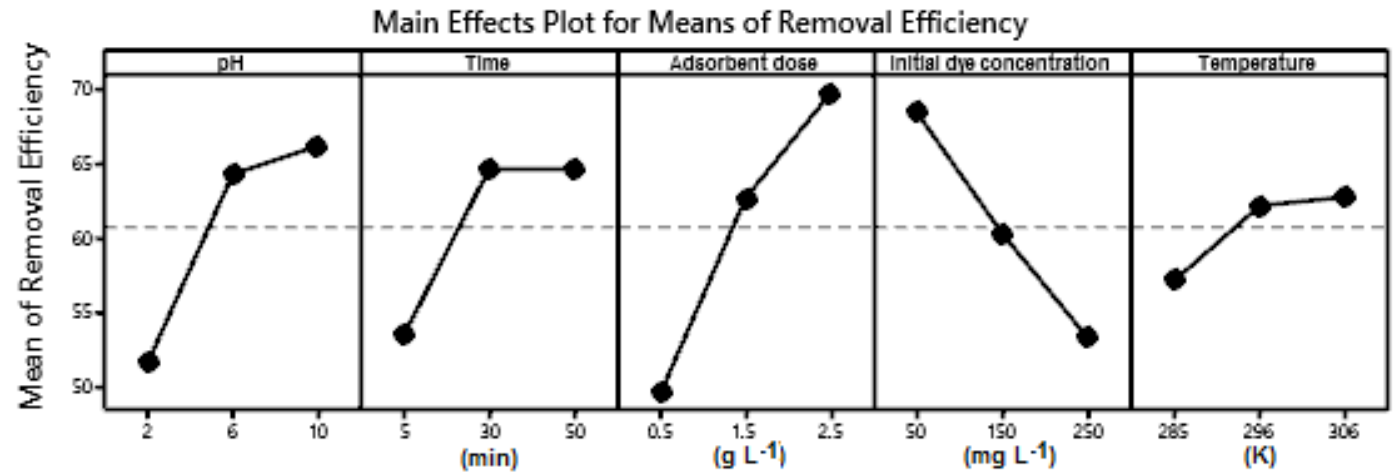

Figure 3. The response curves for the individual effects of dye adsorption parameters on $\mathrm{S} / \mathrm{N}$ ratio and dye removal efficiency.

The adsorbent dose has a greater influence on process efficiency due to the adsorption surface area and the number of sites available for adsorption increase with the adsorbent material dose $[14,36,49]$. Another parameter that has a great influence on the process is $\mathrm{pH}$. Dye removal efficiency increases with the increasing of $\mathrm{pH}$ in the range 2-10. At lower values of $\mathrm{pH}$ the adsorbent surface is positively charged, but with the increase in this parameter the adsorbent surface became negatively charged and favored the electrostatic attraction with MB cations, resulting in a better efficiency [14,36,39]. With the increasing of the initial dye concentration, almost all the adsorption sites on the adsorbents became saturated due to the accumulation of dye molecules on the surface of the adsorbent particle and the removal percentage of the dye decreasing [1]. The impact of contact time was significant at the beginning of the process when a large number of active sites on the adsorbent surface were available for $\mathrm{MB}$ adsorption that generated a rapid increase in dye removal efficiency, until the equilibrium was reached after $30 \mathrm{~min}$. The temperature had a lower influence on the dye removing process from the aqueous solution. The increase in temperature reduces the solution viscosity and has a positive effect on the mobility of the dye cations [39].

The order of the controllable factor influence predicted by the Taguchi design was confirmed by analysis of variance (ANOVA-General Linear Model). Figure 4 illustrates the specific influence of each factor on dye removal by adsorption on DBPH powder. Even though the Taguchi experimental design is based on a limited number of experiments, by analyzing the correlation of the predicted MB removal efficiency with experimental results, it can be observed that the accuracy of the Taguchi method prediction was very good (Figure 5). 


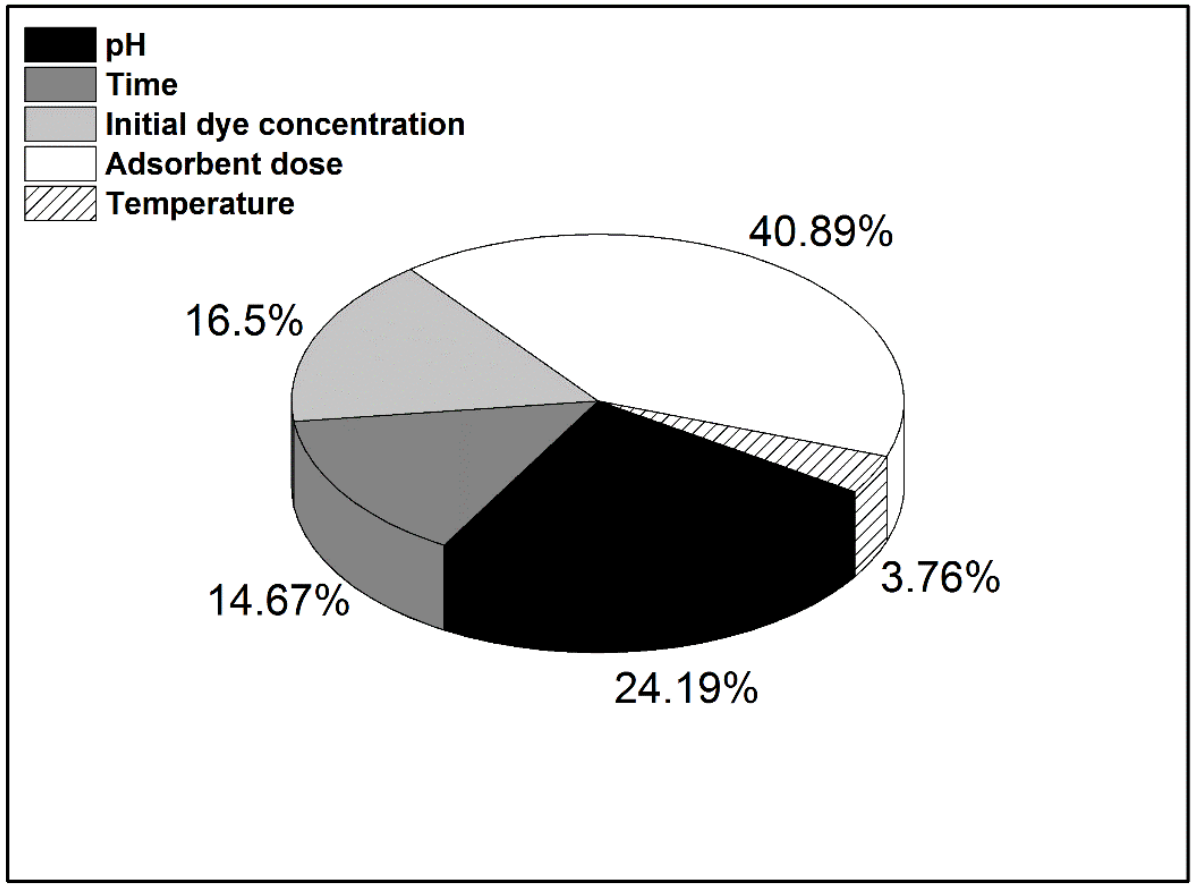

Figure 4. Specific influence of controllable factors on the adsorption process.

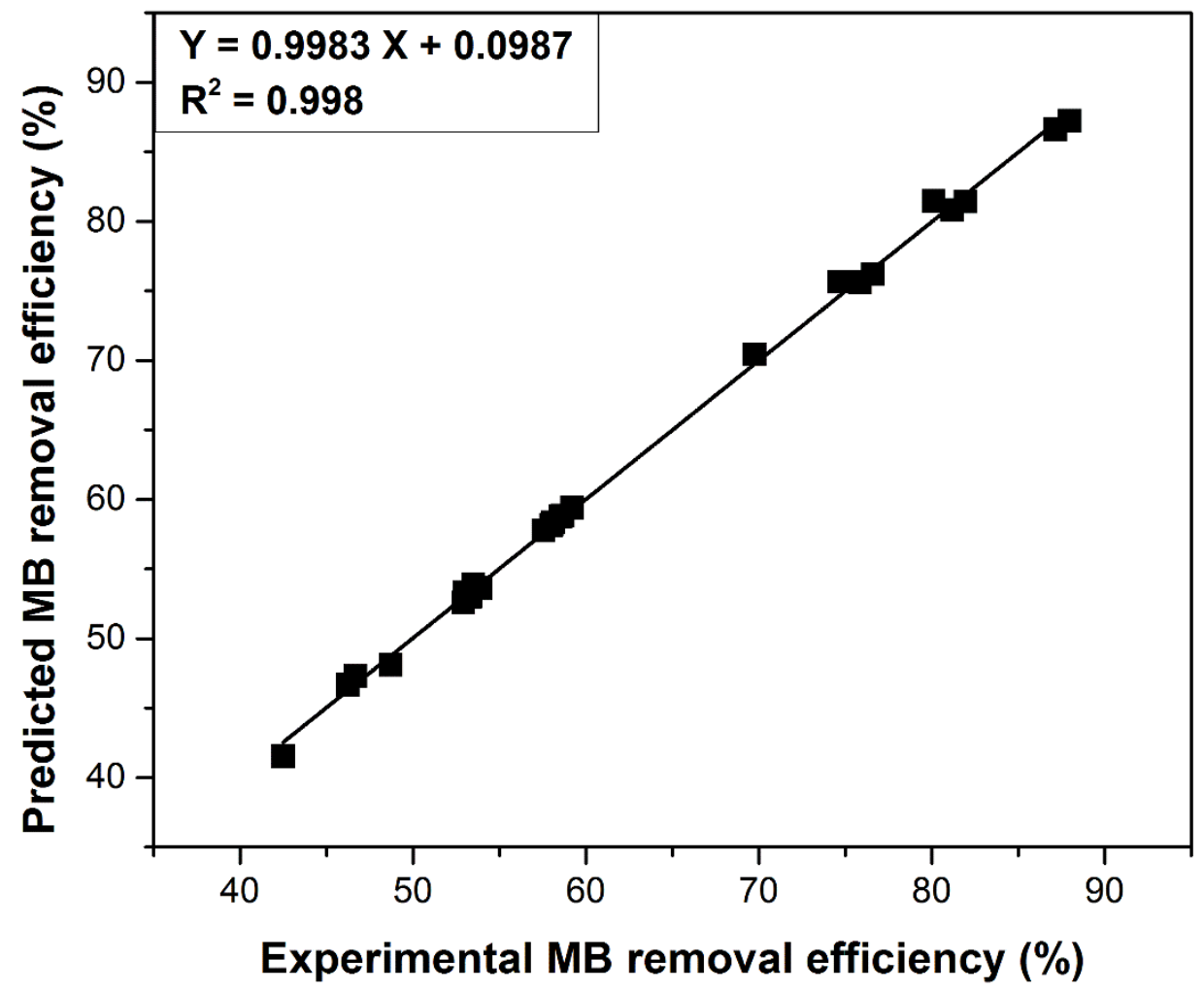

Figure 5. Comparison of experimental and predicted MB removal efficiency.

\subsection{Equilibrium Modeling}

While Langmuir isotherm assumes a monolayer adsorption on a homogeneous surface, Freundlich isotherm considers a multilayer adsorption on a heterogeneous surface, with the sites having different affinity [2,7,19].

Both isotherms are comparatively illustrated in Figure 6. The values of the isotherm's constants, summarized in Table 4, indicate that the adsorption process follows the Langmuir 
isotherm. The maximum adsorption capacity of $121.16\left(\mathrm{mg} \mathrm{g}^{-1}\right)$ is comparable to those previously reported in the literature, even higher than other similar adsorbents (Table 5).

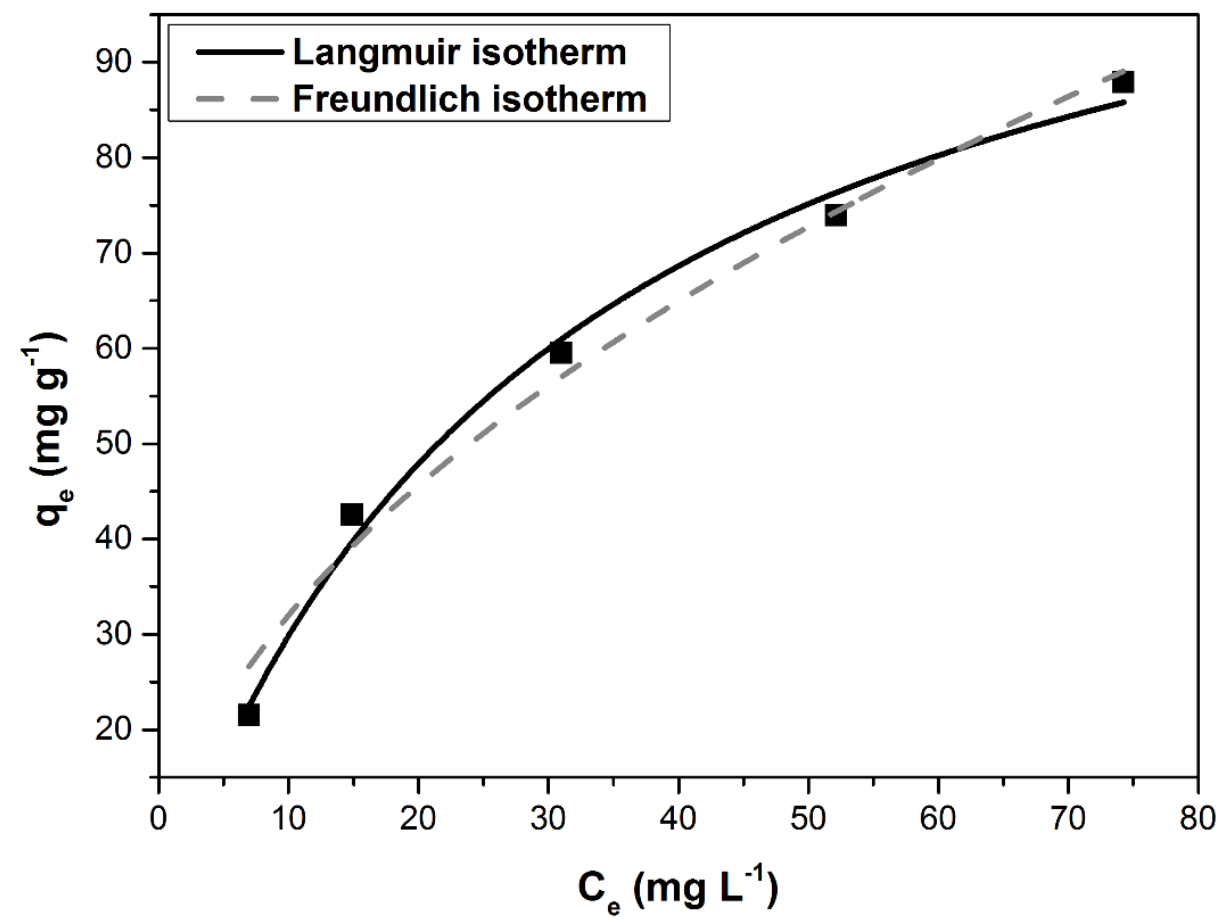

Figure 6. Langmuir and Freundlich isotherms for MB adsorption on DBPH powder.

Table 4. Langmuir and Freundlich adsorption isotherms constants.

\begin{tabular}{ccc}
\hline Isotherm Model & Parameters & Value \\
\hline & $\mathrm{K}_{\mathrm{L}}\left(\mathrm{L} \mathrm{mg}^{-1}\right)$ & $0.032 \pm 0.004$ \\
& $\mathrm{q}_{\max }\left(\mathrm{mg} \mathrm{g}^{-1}\right)$ & $121.16 \pm 7.53$ \\
Langmuir & $\mathrm{R}^{2}$ & 0.9921 \\
& $\mathrm{SSE}$ & 21.51 \\
& $\chi^{2}$ & 0.41 \\
& $\mathrm{ARE}(\%)$ & 3.89 \\
\hline \multirow{3}{*}{ Freundlich } & $\mathrm{K}_{\mathrm{f}}\left(\mathrm{mg} \mathrm{g}^{-1}\right)$ & $9.88 \pm 1.79$ \\
& $1 / \mathrm{n}^{2}$ & $0.51 \pm 0.04$ \\
& $\mathrm{R}$ & 0.9839 \\
& $\mathrm{SSE}$ & 44.79 \\
& $\chi^{2}$ & 1.38 \\
& $\mathrm{ARE}(\%)$ & 6.77 \\
\hline
\end{tabular}

Table 5. Maximum adsorption capacities for a number of previously similar studied adsorbents.

\begin{tabular}{ccc}
\hline Adsorbent Material & Maximum Adsorption Capacity $\mathbf{( \mathbf { m g ~ g } ^ { - \mathbf { 1 } } )}$ & Reference \\
\hline papaya seeds & 555.55 & {$[50]$} \\
corncob & 417.12 & {$[51]$} \\
banana stalks & 322.58 & {$[52]$} \\
shaddock peel & 305.81 & {$[53]$} \\
maize silk powder & 234.10 & {$[54]$} \\
broad bean peels & 192.72 & {$[55]$} \\
mung bean shell & 165.92 & {$[56]$} \\
fava beans & 140.00 & {$[57]$} \\
dry bean pods husk & 121.16 & This study \\
\hline
\end{tabular}


Table 5. Cont.

\begin{tabular}{ccc}
\hline Adsorbent Material & Maximum Adsorption Capacity $\left.\mathbf{~} \mathbf{m} \mathbf{~ g}^{-\mathbf{1}}\right)$ & Reference \\
\hline coffee husks & 90.09 & {$[58]$} \\
garlic peel & 82.64 & {$[59]$} \\
peanut husk & 72.13 & {$[60]$} \\
peanut hull & 68.03 & {$[61]$} \\
oiltea shell & 64.35 & {$[62]$} \\
Daucus carota stem powder & 55.50 & {$[63]$} \\
yellow passion fruit waste & 44.70 & {$[64]$} \\
rice husk & 40.59 & {$[65]$} \\
corn husk & 30.33 & {$[66]$} \\
Bengal gram bean & 24.70 & {$[67]$} \\
banana peel & 20.80 & {$[68]$} \\
mucuna beans & 19.97 & {$[69]$} \\
orange peel & 18.60 & {$[68]$} \\
raw corn cobs & 18.28 & {$[70]$} \\
wheat shells & 16.56 & {$[71]$} \\
\hline
\end{tabular}

\subsection{Kinetic Modeling}

The pseudo-first-order and pseudo-second-order models were used in the kinetic study (Figure 7). Kinetic parameters for these models were summarized in Table 6. The pseudo-second-order kinetic model had a higher value for $\mathrm{R}^{2}$ and smaller values for SSE, $\chi^{2}$ and ARE. Therefore, this model is best suited to describe the adsorption process.

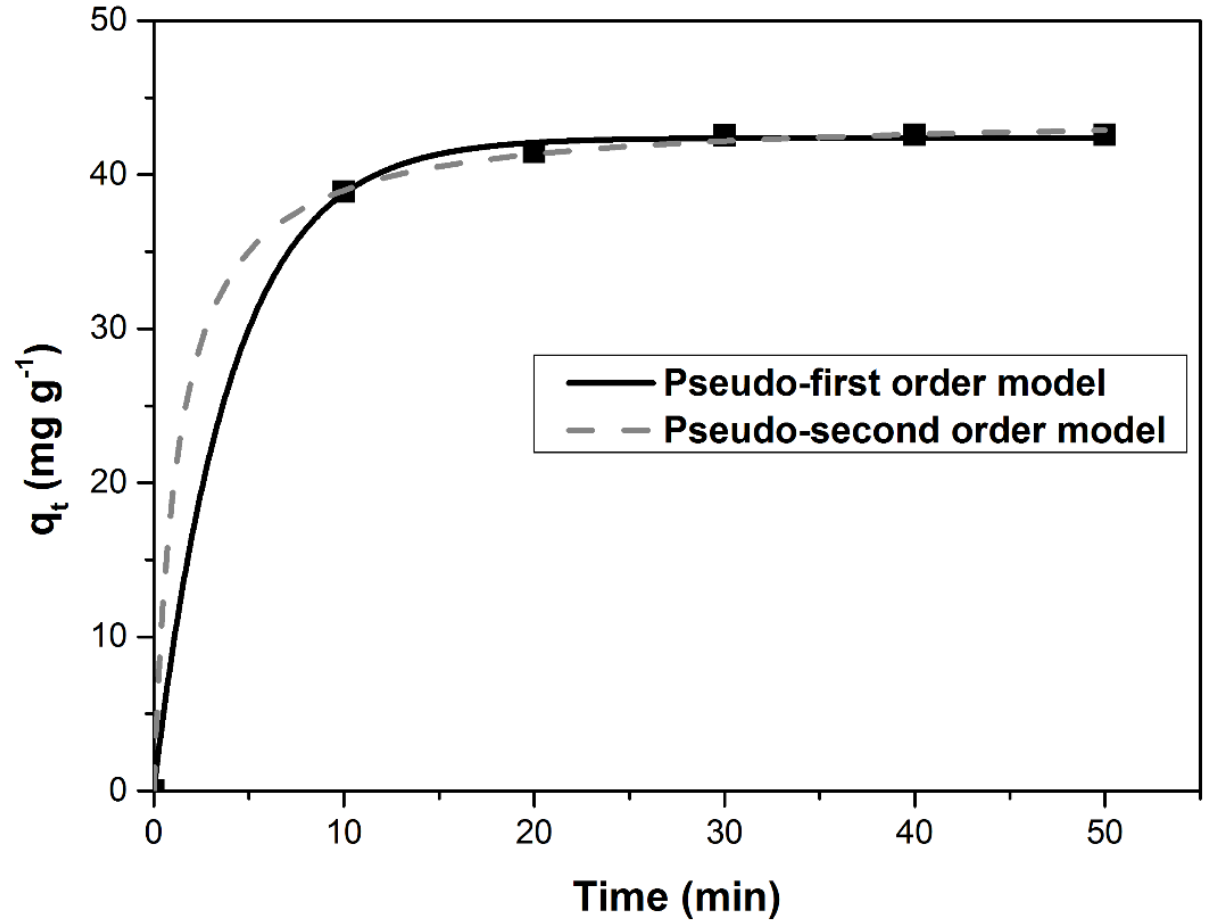

Figure 7. The pseudo-first-order and pseudo-second-order models models tested for MB adsorption on DBPH powder. 
Table 6. Tested kinetic model parameters.

\begin{tabular}{ccc}
\hline Kinetic Model & Parameters & Value \\
\hline & $\mathrm{k}_{1}\left(\mathrm{~min}^{-1}\right)$ & $0.349 \pm 0.029$ \\
& $\mathrm{q}_{\mathrm{e}, \text { calc }}\left(\mathrm{mg} \mathrm{g}^{-1}\right)$ & $41.98 \pm 0.47$ \\
Pseudo-first-order & $\mathrm{R}^{2}$ & 0.9965 \\
& $\mathrm{SSE}$ & 0.45 \\
& $\chi^{2}$ & 0.013 \\
& $\mathrm{ARE}(\%)$ & 20.55 \\
\hline Pseudo-second-order & $\mathrm{k}_{2}\left(\mathrm{~g} \mathrm{mg}^{-1} \mathrm{~min}^{-1}\right)$ & $0.018 \pm 0.001$ \\
& $\mathrm{q}_{\mathrm{e}, \mathrm{calc}}\left(\mathrm{mg} \mathrm{g}^{-1}\right)$ & $43.89 \pm 0.16$ \\
& $\mathrm{R}^{2}$ & 0.9998 \\
& $\mathrm{SSE}$ & 0.26 \\
& $\chi^{2}$ & 0.009 \\
& $\mathrm{ARE}(\%)$ & 20.46 \\
\hline
\end{tabular}

\subsection{Thermodynamic Parameters}

Thermodynamic parameters, calculated based on the plot presented in Figure 8 and mentioned in Table 7, suggests an endothermic $\left(\Delta \mathrm{G}^{0}<0, \Delta \mathrm{H}^{0}>0\right)$, spontaneous and favorable adsorption process. $\Delta S^{0}>0$ indicates the affinity of adsorbent material for dye $[8,14]$. The physisorption is involved in the MB adsorption process when $\Delta \mathrm{H}^{0}<40\left(\mathrm{~kJ} \mathrm{~mol}^{-1}\right)[72,73]$. In addition, when $\Delta \mathrm{H}^{0}<\left(20 \mathrm{~kJ} \mathrm{~mol}^{-1}\right)$, the physical adsorption is affected by van der Waals interactions [74]. Generally, $\Delta \mathrm{G}^{0}$ values ranged between $-20\left(\mathrm{~kJ} \mathrm{~mol}^{-1}\right)$ up to $0\left(\mathrm{~kJ} \mathrm{~mol}^{-1}\right)$ and indicate that physical adsorption is involved, while $\Delta \mathrm{G}^{0}$ ranging between -80 and $-200\left(\mathrm{~kJ} \mathrm{~mol}^{-1}\right)$ suggests a possible chemisorption process. The calculated value presented in Table 7 suggests an adsorption based on physisorption and enhanced by a small chemical effect [40].

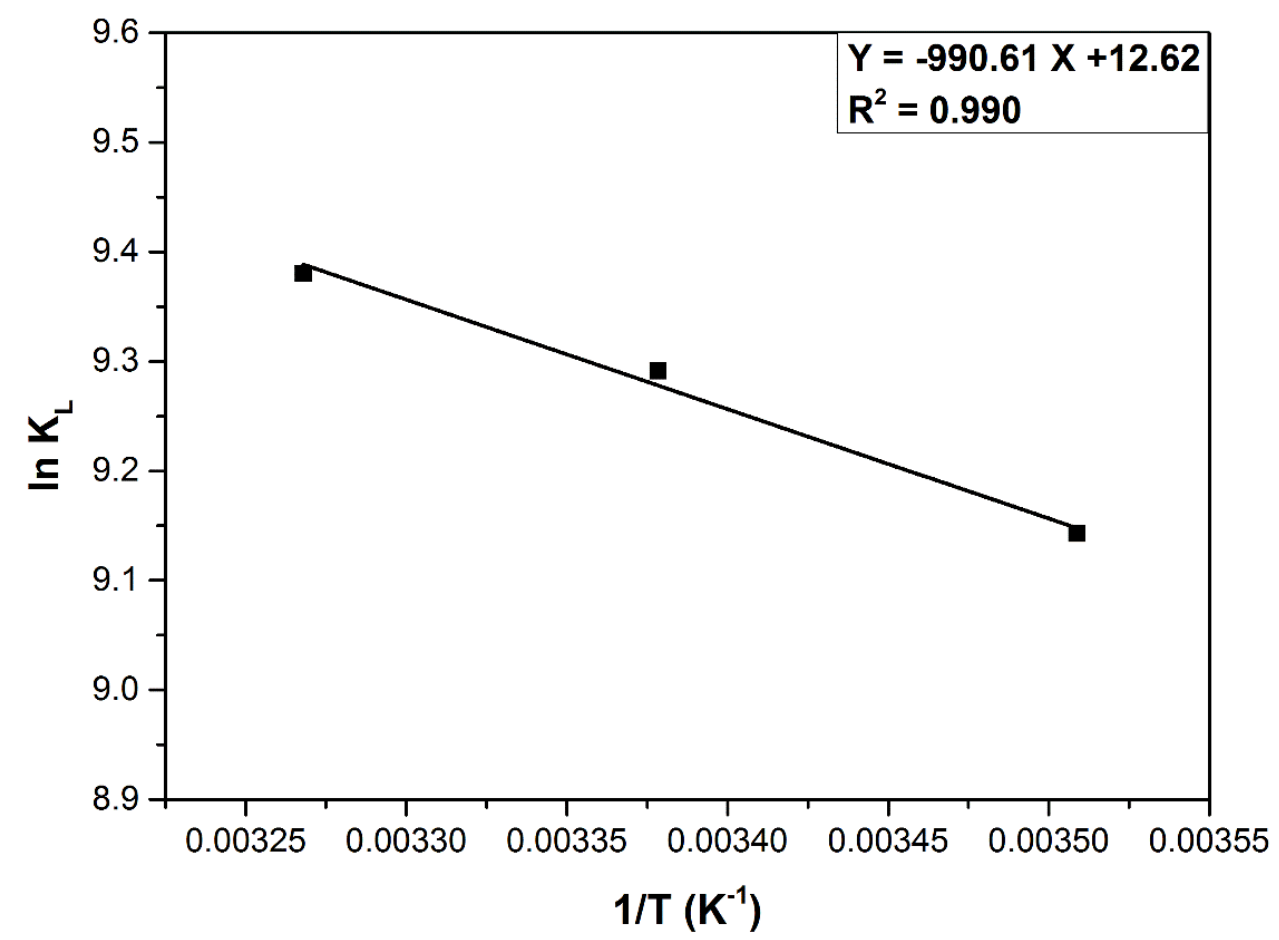

Figure 8. Plot of $\ln \mathrm{K}_{\mathrm{L}}$ vs. $1 / \mathrm{T}$ for MB adsorption on $\mathrm{DBPH}$ powder. 
Table 7. Thermodynamic parameters for MB adsorption on DBPH powder.

\begin{tabular}{|c|c|c|c|c|}
\hline \multicolumn{3}{|c|}{$\Delta \mathrm{G}\left(\mathrm{kJ} \mathrm{mol}{ }^{-1}\right)$} & \multirow{2}{*}{ 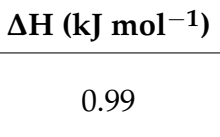 } & \multirow{2}{*}{$\frac{\Delta \mathbf{S}\left(\mathrm{J} \mathrm{mol}^{-\mathbf{1}} \mathbf{K}^{-1}\right)}{12.62}$} \\
\hline $\begin{array}{c}285 \mathrm{~K} \\
-21.66\end{array}$ & $\begin{array}{c}296 \mathrm{~K} \\
-22.86\end{array}$ & $\begin{array}{c}306 \mathrm{~K} \\
-23.86\end{array}$ & & \\
\hline
\end{tabular}

\subsection{Desorption Studies}

In order to consider the regeneration possibility of adsorbent material, the desorption studies were performed in three different media (acid, neutral and basic). Figure 9 shows the desorption efficiency of the tested regeneration agents. The acid was found as being the best desorbing reagent with efficiency of about $85 \%$.

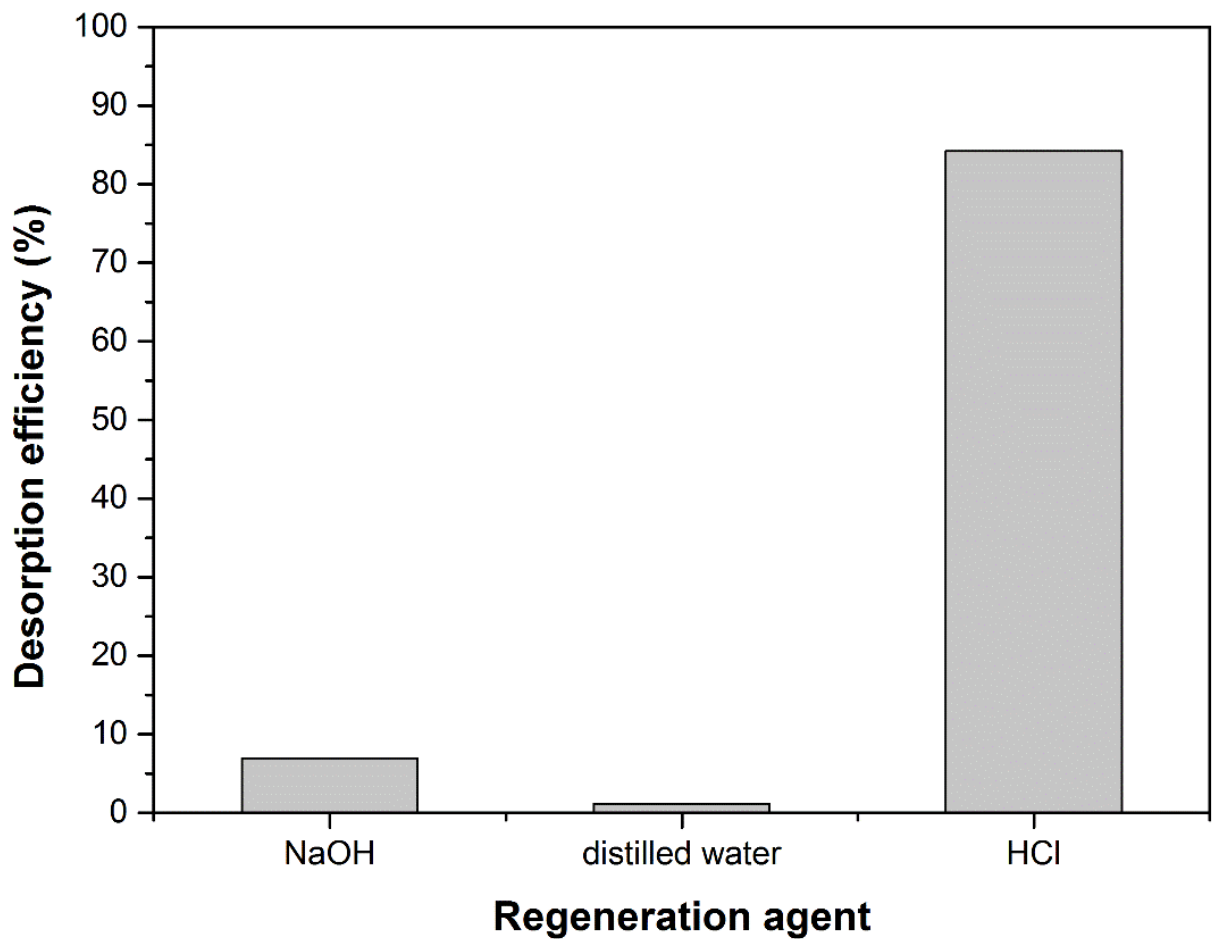

Figure 9. The desorption efficiency in three different media.

The efficiency of the adsorption process after several adsorption-regeneration cycles was studied in the next stage of experimental determinations. The results are shown in Figure 10. It can be seen that the efficiency of the dye removal process decreased after each adsorption-regeneration cycle. If initially this parameter was $87 \%$ after the first cycle, it decreased to $73 \%$, and after the second cycle it reached $15 \%$. Practically only the first regeneration cycle is recommended, after which the adsorbent material has a lower performance. DBPH powder is cheap and easily available in large quantities; therefore, we consider that regeneration is not mandatory. 


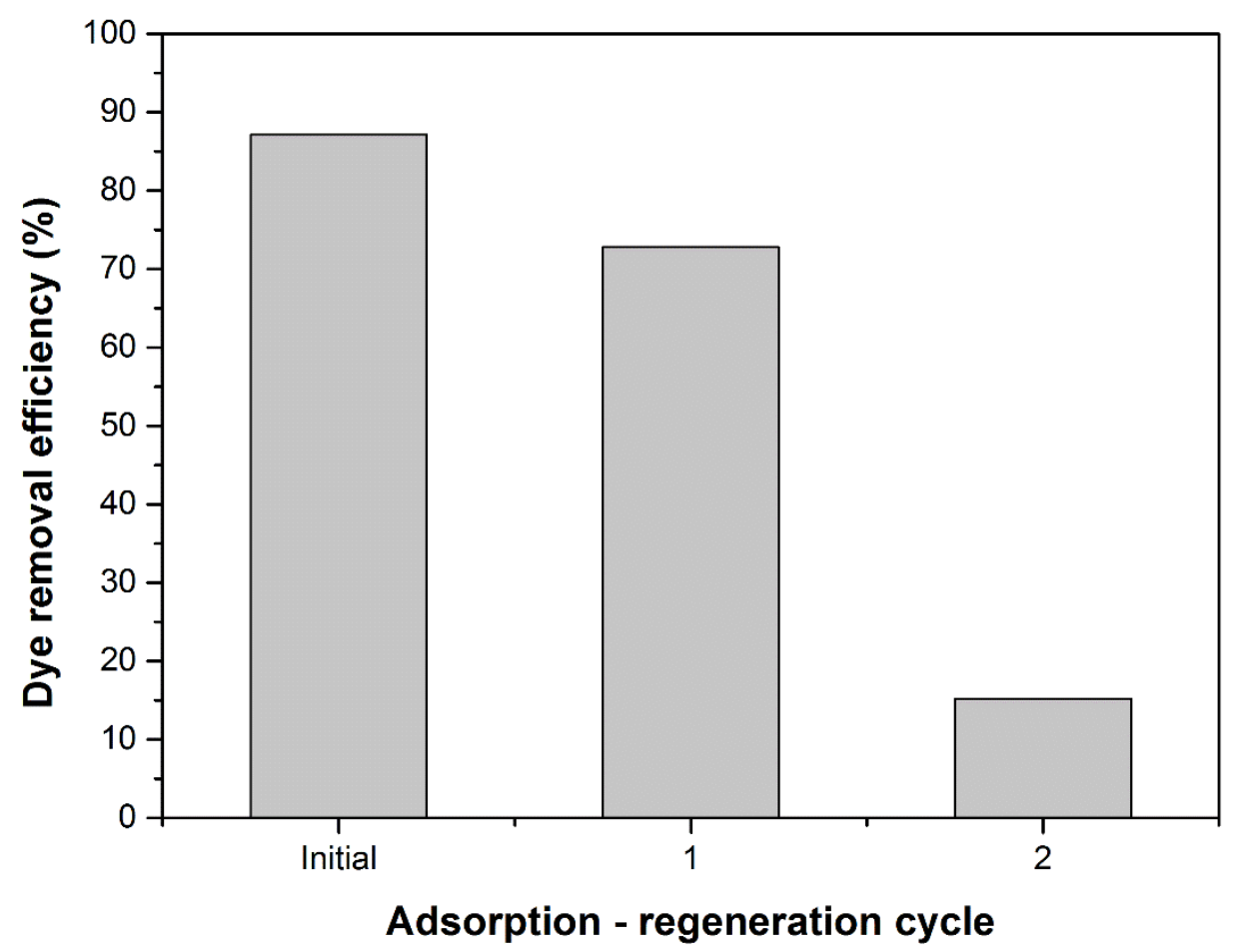

Figure 10. Dye removal efficiency after each adsorption-regeneration cycle.

\section{Conclusions}

The dye removal efficiency by adsorption on dry bean pods husks powder is influenced by solution $\mathrm{pH}$, contact time, initial dye concentration and adsorbent dose. The Taguchi (L27) experimental design showed that the most influential factor was adsorbent dose (with a percent contribution, established by the ANOVA (General Linear Model) analysis, of $40.89 \%$ ), followed by $\mathrm{pH}$, initial dye concentration, time and temperature. The accuracy of the Taguchi method prediction was very good $\left(R^{2}=0.998\right)$. Langmuir isotherm and pseudo-second-order kinetic model describe the adsorption process. These kinetic and equilibrium models had greater values for $R^{2}$ and smaller values for SSE, $\chi^{2}$ and ARE. The maximum adsorption capacity, $121.16\left(\mathrm{mg} \mathrm{g}^{-1}\right)$, was higher compared to other similar adsorbents reported in the literature. The thermodynamic parameter values indicate a spontaneous, favorable and endothermic $\left(\Delta \mathrm{G}^{0}<0, \Delta \mathrm{H}^{0}>0\right)$ adsorption process. Furthermore, they denote those electrostatic forces and van der Waals interactions are implied in the physical adsorption process $\left(\Delta \mathrm{H}^{0}<20 \mathrm{~kJ} \mathrm{~mol}^{-1}\right)$. The desorption studies performed in three different media (acid, neutral and basic) showed that the acid was the best desorbing reagent with an efficiency of about $85 \%$. The efficiency of the adsorption process after several adsorption-regeneration cycles decreased after each cycle. After the second cycle it reached $15 \%$. The obtained results, and the fact that adsorbent material is cheap and easily available, recommend DBPH powder as an efficient, low-cost adsorbent for methylene blue removal from aqueous media and the Taguchi method as a very suitable adsorption optimization algorithm.

Author Contributions: Conceptualization, G.M., C.V. and S.P.; methodology, G.M.; software, G.M. and C.V.; validation, G.M.; formal analysis, G.M., C.V. and S.P.; investigation, G.M., S.P. and S.B.; resources, G.M.; data curation, G.M.; writing—original draft preparation, G.M., C.V., S.P. and S.B.; writing-review and editing, G.M., C.V. and S.P.; visualization, G.M.; supervision, G.M. All authors have read and agreed to the published version of the manuscript.

Funding: This research received no external funding.

Institutional Review Board Statement: Not applicable.

Informed Consent Statement: Not applicable. 
Data Availability Statement: All the experimental data obtained are presented, in the form of tables and/or figures, in the article.

Conflicts of Interest: The authors declare no conflict of interest.

\section{References}

1. Alghamdi, W.M.; El Mannoubi, I. Investigation of Seeds and Peels of Citrullus colocynthis as Efficient Natural Adsorbent for Methylene Blue Dye. Processes 2021, 9, 1279. [CrossRef]

2. Alvarez-Torrellas, S.; Boutahala, M.; Boukhalfa, N.; Munoz, M. Effective Adsorption of Methylene Blue dye onto Magnetic Nanocomposites. Modeling and Reuse Studies. Appl. Sci. 2019, 9, 4563. [CrossRef]

3. De Luca, P.; Nagy, J.B. Treatment of Water Contaminated with Reactive Black-5 Dye by Carbon Nanotubes. Materials 2020, 13, 5508. [CrossRef]

4. Ge, M.; Xi, Z.; Zhu, C.; Liang, G.; Yang, Y.; Hu, G.; Jamal, L.; Jahangir Alam, S.M. Adsorption Process and Properties Analyses of a Pure Magadiite and a Modified Magadiite on Rhodamine-B from an Aqueous Solution. Processes 2019, 7, 565. [CrossRef]

5. Gong, J.; Liu, J.; Jiang, Z.; Wen, X.; Mijowska, E.; Tang, T.; Chen, X. A facile approach to prepare porous cup-stacked carbon nanotube with high performance in adsorption of methylene blue. J. Colloid. Interface. Sci. 2015, 445, 195-204. [CrossRef]

6. Kweinor Tetteh, E.; Rathilal, S. Adsorption and Photocatalytic Mineralization of Bromophenol Blue Dye with $\mathrm{TiO}_{2} \mathrm{Modified}_{\mathrm{i}}$ with Clinoptilolite/Activated Carbon. Catalysts 2021, 11, 7. [CrossRef]

7. Rojas, J.; Suarez, D.; Moreno, A.; Silva-Agredo, J.; Torres-Palma, R.A. Kinetics, Isotherms and Thermodynamic Modeling of Liquid Phase Adsorption of Crystal Violet Dye onto Shrimp-Waste in Its Raw, Pyrolyzed Material and Activated Charcoals. Appl. Sci. 2019, 9, 5337. [CrossRef]

8. Setiabudi, H.D.; Jusoh, R.; Suhaimi, S.F.R.M.; Masrur, S.F. Adsorption of methylene blue onto oil palm (Elaeis guineensis) leaves: Process optimization, isotherm, kinetics and thermodynamic studies. J. Taiwan Inst. Chem. Eng. 2016, 63, 363-370. [CrossRef]

9. Valerio Filho, A.; Xavare Kulman, R.; Vaz Tholozan, L.; Felkl de Almeida, A.R.; Silveira da Rosa, G. Preparation and Characterization of Activated Carbon Obtained from Water Treatment Plant Sludge for Removal of Cationic Dye from Wastewater. Processes 2020, 8, 1549. [CrossRef]

10. Abualnaja, K.M.; Alprol, A.E.; Abu-Saied, M.A.; Ashour, M.; Mansour, A.T. Removing of Anionic Dye from Aqueous Solutions by Adsorption Using of Multiwalled Carbon Nanotubes and Poly (Acrylonitrile-styrene) Impregnated with Activated Carbon. Sustainability 2021, 13, 7077. [CrossRef]

11. Cai, X.; Li, J.; Liu, Y.; Hu, X.; Tan, X.; Liu, S.; Wang, H.; Gu, Y.; Luo, L. Design and Preparation of Chitosan-Crosslinked Bismuth Ferrite/Biochar Coupled Magnetic Material for Methylene Blue Removal. Int. J. Environ. Res. Public Health 2020, 17, 6. [CrossRef]

12. Mokhtar, N.; Aziz, E.A.; Aris, A.; Ishak, W.F.W.; Ali, N.S.M. Biosorption of azo-dye using marine macro-alga of Euchema Spinosum. J. Environ. Chem. Eng. 2017, 5, 5721-5731. [CrossRef]

13. Reddy, P.M.K.; Verma, P.; Subrahmanyam, C. Bio-waste derived adsorbent material for methylene blue adsorption. J. Taiwan Inst. Chem. Eng. 2016, 58, 500-508. [CrossRef]

14. Shakoor, S.; Nasar, A. Removal of methylene blue dye from artificially contaminated water using citrus limetta peel waste as a very low cost adsorbent. J. Taiwan. Inst. Chem. Eng. 2016, 66, 154-163. [CrossRef]

15. Hakami, A.A.H.; Wabaidur, S.M.; Khan, M.A.; AlOthman, Z.A.; Siddiqui, M.R. Extraction Procedures and Analytical Methods for the Determination of Methylene Blue, Rhodamine B and Crystal Violet-An Overview. Curr. Anal. Chem. 2021, 17, 708-728. [CrossRef]

16. Iwuozor, K.O.; Ighalo, J.O.; Ogunfowora, L.A.; Adeniyi, A.G.; Igwegbe, C.A. An empirical literature analysis of adsorbent performance for methylene blue uptake from aqueous media. J. Environ. Chem. Eng. 2021, 9, 105658. [CrossRef]

17. Santoso, E.; Ediati, R.; Kusumawati, Y.; Bahruji, H.; Sulistiono, D.O.; Prasetyoko, D. Review on recent advances of carbon based adsorbent for methylene blue removal from waste water. Mater. Today Chem. 2020, 16, 100233. [CrossRef]

18. Kadhom, M.; Albayati, N.; Alalwan, H.; Al-Furaiji, M. Removal of dyes by agricultural waste. Sustain. Chem. Pharm. 2020, 16, 100259. [CrossRef]

19. Fernandez-Lopez, J.A.; Angosto, J.M.; Roca, M.J.; Doval Minarro, M. Taguchi design-based enhancement of heavy metals bioremoval by agroindustrial waste biomass from artichoke. Sci. Total Environ. 2019, 653, 55-63. [CrossRef] [PubMed]

20. Ghorbani, F.; Kamari, S. Application of response surface methodology for optimization of methyl orange adsorption by Fe-grafting sugar beet bagasse. Adsorp. Sci. Technol. 2017, 35, 317-338. [CrossRef]

21. Korake, S.R.; Jadhao, P.D. Investigation of Taguchi optimization, equilibrium isotherms, and kinetic modeling for cadmium adsorption onto deposited silt. Heliyon 2020, 6, e05755.

22. Madan, S.S.; Wasewar, K.L. Optimization for benzeneacetic acid removal from aqueous solution using CaO2 nanoparticles based on Taguchi method. J. Appl. Res. Technol. 2017, 15, 332-339. [CrossRef]

23. Razmi, B.; Ghasemi-Fasaei, R. Investigation of Taguchi optimization, equilibrium isotherms, and kinetic modeling for phosphorus adsorption onto natural zeolite of clinoptilolite type. Adsorp. Sci. Technol. 2018, 36, 1470-1483. [CrossRef]

24. Shojaei, S.; Shojaei, S.; Band, S.S.; Farizhandi, A.A.K.; Ghoroqi, M.; Mosavi, A. Application of Taguchi method and response surface methodology into the removal of malachite green and auramine-O by NaX nanozeolites. Sci. Rep. 2021, 11,16054 . [CrossRef] [PubMed] 
25. Aita, C.A.G.; Goss, I.C.; Rosendo, T.S.; Tier, M.D.; Wiedenhoft, A.; Reguly, A. Shear strength optimization for FSSW AA6060-T5 joints by Taguchi and full factorial design. J. Mater. Res. Technol. 2020, 9, 16072-16079. [CrossRef]

26. Taiwo, A.E.; Madzimbamuto, T.N.; Ojumu, T.V. Optimization of process variables for acetoin production in a bioreactor using Taguchi orthogonal array design. Heliyon 2020, 6, e05103. [CrossRef]

27. Belmiro, R.H.; Tribst, A.A.L.; Cristianini, M. Impact of high pressure processing in hydration and drying curves of common beans (Phaseolus vulgaris L.). Innov. Food Sci. Emerg. Technol. 2018, 47, 279-285. [CrossRef]

28. Corzo-Rios, L.J.; Sanchez-Chino, X.M.; Cardador-Martinez, A.; Martinez-Herrera, J.; Jimenez-Martinez, C. Effect of cooking on nutritional and non-nutritional compounds in two species of Phaseolus (P. vulgaris and P. coccineus) cultivated in Mexico. Int. J. Gastron. Food Sci. 2020, 20, 100206.

29. Salama, D.M.; Osman, S.A.; Abd El-Aziz, M.E.; Abd Elwahed, M.S.A.; Shaaban, E.A. Effect of zinc oxide nanoparticles on the growth, genomic DNA, production and the quality of common dry bean (Phaseolus vulgaris). Biocatal. Agric. Biotechnol. 2019, 18, 101083. [CrossRef]

30. Ghosh, S.B.; Mondal, N.K. Application of Taguchi method for optimizing the process parameters for the removal of fluoride by Al-impregnated Eucalyptus bark ash. Environ. Nanotechnol. Monit. Manag. 2019, 11, 100206. [CrossRef]

31. Santra, D.; Joarder, R.; Sarkar, M. Taguchi design and equilibrium modeling for fluoride adsorption on cerium loaded cellulose nanocomposite bead. Carbohydr. Polym. 2014, 111, 813-821. [CrossRef]

32. Zolgharnein, J.; Rastgordani, M. Optimization of simultaneous removal of binary mixture of indigo carmine and methyl orange dyes by cobalt hydroxide nano-particles through Taguchi method. J. Mol. Liq. 2018, 262, 405-414. [CrossRef]

33. Rahmani, M.; Kaykhaii, M.; Sasani, M. Application of Taguchi L16 design method for comparative study of ability of 3A zeolite in removal of Rhodamine B and Malachite green from environmental water samples. Spectrochim. Acta. Part A 2018, 188, 164-169. [CrossRef]

34. Postai, D.L.; Demarchi, C.A.; Zanatta, F.; Melo, D.C.C.; Rodrigues, C.A. Adsorption of rhodamine B and methylene blue dyes using waste of seeds of Aleurites Moluccana, a low cost adsorbent. Alex. Eng. J. 2016, 55, 1713-1723. [CrossRef]

35. Spagnoli, A.A.; Giannakoudakis, D.A.; Bashkova, S. Adsorption of methylene blue on cashew nut shell based carbons activated with zinc chloride: The role of surface and structural parameters. J. Mol. Liq. 2017, 229, 465-471. [CrossRef]

36. Han, R.; Zou, W.; Yu, W.; Cheng, S.; Wang, Y.; Shi, J. Biosorption of methylene blue from aqueous solution by fallen phoenix tree's leaves. J. Hazard. Mater. 2007, 141, 156-162. [CrossRef]

37. Dotto, G.L.; Salau, N.P.G.; Piccin, J.S.; Cadaval, T.R.S.; de Pinto, L.A.A. Adsorption Kinetics in Liquid Phase: Modeling for Discontinuous and Continuous Systems. In Adsorption Processes for Water Treatment and Purification; Bonilla-Petriciolet, A., Mendoza-Castillo, D., Reynel-Avila, H., Eds.; Springer: Cham, Switzerland, 2017; pp. 53-76.

38. Piccin, J.S.; Cadaval, T.R.S.; de Pinto, L.A.A.; Dotto, G.L. Adsorption Isotherms in Liquid Phase: Experimental, Modeling, and Interpretations. In Adsorption Processes for Water Treatment and Purification; Bonilla-Petriciolet, A., Mendoza-Castillo, D., Reynel-Avila, H., Eds.; Springer: Cham, Switzerland, 2017; pp. 19-51.

39. Pang, J.; Fu, F.; Ding, Z.; Lu, J.; Li, N.; Tang, B. Adsorption behaviors of methylene blue from aqueous solution on mesoporous birnessite. J. Taiwan Inst. Chem. Eng. 2017, 77, 168-176. [CrossRef]

40. Weng, C.H.; Lin, Y.T.; Tzeng, T.W. Removal of methylene blue from aqueous solution by adsorption onto pineapple leaf powder. J. Hazard. Mater. 2009, 170, 417-424. [CrossRef]

41. Blazquez, G.; Martin-Lara, M.A.; Tenorio, G.; Calero, M. Batch biosorption of lead(II) from aqueous solutions by olive tree pruning waste: Equilibrium, kinetics and thermodynamic study. Chem. Eng. J. 2011, 168, 170-177. [CrossRef]

42. Wang, Z.L.; Liu, Y.X.; Peng, J.H.; Zhang, R.Q. Hemicelluloses extraction of bagasse with NaOH/borax. Adv. Mat. Res. 2012, 610-613, 3367-3370. [CrossRef]

43. Pekel Bayramgil, N. Preparation of graft copolymers of cellulose derivatives and their use in recovery processes. In Cellulose-Based Graft Copolymers: Structure and Chemistry, 1st ed.; Thakur, V.K., Ed.; CRC Press: Boca Raton, FL, USA, 2015 ; pp. 335-364.

44. Wulandari, W.T.; Rochliadi, A.; Arcana, I.M. Nanocellulose prepared by acid hydrolysis of isolated cellulose from sugarcane bagasse. IOP Conf. Ser. Mat. Sci. Eng. 2016, 107, 012045. [CrossRef]

45. Cheng, S.; Huang, A.; Wang, S.; Zhang, Q. Effect of different heat treatment temperatures on the chemical composition and structure of Chinese Fir wood. BioResources 2016, 11, 4006-4016. [CrossRef]

46. Saravanakumar, S.S.; Kumaravel, A.; Nagarajan, T.; Moorthy, I.G. Effect of chemical treatments on physicochemical properties of Prosopis juliflora fibers. Int. J. Polym. Anal. Charact. 2014, 19, 383-390. [CrossRef]

47. Lupoi, J.S.; Smith-Moritz, A.; Singh, S.; McQualter, R.; Scheller, H.V.; Simmons, B.A.; Henry, R.J. Localization of polyhydroxybutyrate in sugarcane using Fourier-transform infrared microspectroscopy and multivariate imaging. Biotechnol. Biofuels 2015, 8, 98. [CrossRef]

48. Ali, M.E.; Yong, C.K.; Ching, Y.C.; Chuah, C.H.; Liou, N.S. Effect of single and double stage chemically treated kenaf fibers on mechanical properties of polyvinyl alcohol film. BioResources 2015, 10, 822-838. [CrossRef]

49. Mosoarca, G.; Vancea, C.; Popa, S.; Boran, S.; Tanasie, C. A green approach for treatment of wastewater with manganese using wood ash. J. Chem. Technol. Biotechnol. 2020, 95, 1781-1789. [CrossRef]

50. Hameed, B.H. Evaluation of papaya seeds as a novel non-conventional low-cost adsorbent for removal of methylene blue. $J$. Hazard. Mater. 2009, 162, 939-944. [CrossRef] 
51. Choi, H.J.; Yu, S.W. Biosorption of methylene blue from aqueous solution by agricultural bioadsorbent corncob. Environ. Eng. Res. 2019, 24, 99-106. [CrossRef]

52. Mahadlek, J.; Mahadlek, J. Investigation of various factors affecting methylene blue adsorption on agricultural waste: Banana stalks. Sci. Eng. Health Stud. 2020, 14, 47-61.

53. Liang, J.; Wu, J.; Li, P.; Wang, X.; Yang, B. Shaddock peel as a novel low-cost adsorbent for removal of methylene blue from dye wastewater. Desalin. Water. Treat. 2012, 39, 70-75. [CrossRef]

54. Miraboutalebi, S.M.; Nikouzad, S.K.; Peydayesh, M.; Allahgholi, N.; Vafajoo, L.; McKay, G. Methylene blue adsorption via maize silk powder: Kinetic, equilibrium, thermodynamic studies and residual error analysis. Process Saf. Environ. Prot. 2017, 106, 191-202. [CrossRef]

55. Hameed, B.H.; El-Khaiary, M.I. Sorption kinetics and isotherm studies of a cationic dye using agricultural waste: Broad bean peels. J. Hazard. Mater. 2008, 154, 639-648. [CrossRef] [PubMed]

56. Zhou, H.; Feng, Y.F.; Wu, Y.H.; Yang, L.Z. Mung Bean Shell (Vigna radiata L. Wilczek)-A Novel Cost-Effective Adsorbent for Removing Methylene Blue from Aqueous Solutions. AMR 2012, 573-574, 68-79. [CrossRef]

57. Bayomie, O.S.; Kandeel, H.; Shoeib, T.; Yang, H.; Youssef, N.; El-Sayed, M.M.H. Novel approach for effective removal of methylene blue dye from water using fava bean peel waste. Sci. Rep. 2020, 10, 7824. [CrossRef] [PubMed]

58. Oliveira, L.S.; Franca, A.S.; Alves, T.M.; Rocha, S.D.F. Evaluation of untreated coffee husks as potential biosorbents for treatment of dye contaminated waters. J. Hazard. Mater. 2008, 155, 507-512. [CrossRef] [PubMed]

59. Hameed, B.H.; Ahmad, A.A. Batch adsorption of methylene blue from aqueous solution by garlic peel, an agricultural waste biomass. J. Hazard. Mater. 2009, 164, 870-875. [CrossRef] [PubMed]

60. Song, J.; Zou, W.; Bian, Y.; Su, F.; Han, R. Adsorption characteristics of methylene blue by peanut husk in batch and column modes. Desalination 2011, 265, 119-125. [CrossRef]

61. Gong, R.; Li, M.; Yang, C.; Sun, Y.; Chen, J. Removal of cationic dyes from aqueous solution by adsorption on peanut hull. J. Hazard. Mater. 2005, 121, 247-250. [CrossRef]

62. Liu, J.; Li, E.; You, X.; Hu, C.; Huang, Q. Adsorption of methylene blue on an agro-waste oiltea shell with and without fungal treatment. Sci. Rep. 2016, 6, 38450. [CrossRef]

63. Kushwaha, A.K.; Gupta, N.; Chattopadhyaya, M.C. Removal of cationic methylene blue and malachite green dyes from aqueous solution by waste materials of Daucus carota. J. Saudi. Chem. Soc. 2014, 18, 200-207. [CrossRef]

64. Pavan, F.A.; Mazzocato, A.C.; Gushikem, Y. Removal of methylene blue dye from aqueous solutions by adsorption using yellow passion fruit peel as adsorbent. Bioresour. Technol. 2008, 99, 3162-3165. [CrossRef]

65. Vadivelan, V.; Kumar, K.V. Equilibrium, kinetics, mechanism and process design for the sorption of methylene blue onto rice husk. J. Colloid Interf. Sci. 2005, 286, 90-100. [CrossRef]

66. Malik, D.S.; Jain, C.K.; Yadav, A.K.; Kothari, R.; Pathak, V.V. Removal of methylene blue dye in aqueous solution by agricultural waste. Int. Res. J. Eng. Tech. 2016, 3, 864-880.

67. Pal, P.; Pal, A. Bengal Gram Husk as Efficient and Cost-Effective Adsorbent for $\mathrm{Pb}^{2+}$ and Methylene Blue Removal in Single and Binary Systems. J. Hazard. Toxic Radioact. Waste 2020, 24, 04019032. [CrossRef]

68. Annadurai, G.; Juang, R.S.; Lee, D.J. Use of cellulose-based wastes for adsorption of dyes from aqueous solutions. J. Hazard. Mater. 2002, 92, 263-274. [CrossRef]

69. Shooto, N.D.; Nkutha, C.S.; Guilande, N.R.; Naidoo, E.B. Pristine and modified mucuna beans adsorptive studies of toxic lead ions and methylene blue dye from aqueous solution. S. Afr. J. Chem. Eng. 2020, 31, 33-43. [CrossRef]

70. Conrad, E.K.; Nnaemeka, O.J.; Chris, A.O. Adsorptive removal of methylene blue from aqueous solution using agricultural waste: Equilibrium, kinetic and thermodynamic studies. Am. J. Chem. Mater. Sci. 2015, 2, 14-25.

71. Bulut, Y.; Aydin, H. A kinetics and thermodynamics study of methylene blue adsorption on wheat shells. Desalination 2006, 194, 259-267. [CrossRef]

72. Dawood, S.; Sen, T.K.; Phan, C. Adsorption removal of Methylene Blue (MB) dye from aqueous solution by bio-char prepared from Eucalyptus sheathiana bark: Kinetic, equilibrium, mechanism, thermodynamic and process design. Desalin. Water Treat. 2016, 57, 28964-28980. [CrossRef]

73. Wakkel, M.; Khiari, B.; Zagrouba, F. Textile wastewater treatment by agro-industrial waste: Equilibrium modelling, thermodynamics and mass transfer mechanisms of cationic dyes adsorption onto low-cost lignocellulosic adsorbent. J. Taiwan Inst. Chem. Eng. 2019, 96, 439-452. [CrossRef]

74. Jiang, Z.; Hu, D. Molecular mechanism of anionic dyes adsorption on cationized rice husk cellulose from agricultural wastes. J. Mol. Liq. 2019, 276, 105-114. [CrossRef] 